\title{
PENGARUH CURRENT RATIO DAN DEBT TO EQUITY RATIO TERHADAP NILAI PERUSAHAAN PADA PT ASTRA INTERNATIONAL TBK PERIODE 2009-2019
}

\author{
1Vivi Wulandari, ${ }^{2 *}$ Suharni Rahayu \\ Universitas Pamulang, Tangerang, Banten, Indonesia \\ *dosen00964@unpam.ac.id
}

\begin{abstract}
Abstrak
Penelitian ini bertujuan untuk mengetahui Pengaruh Current Ratio (CR) dan Debt to Equity Ratio (DER) terhadap Return on Asset (ROA) Pada PT Astra International, Tbk secara parsial dan simultan. Metode yang digunakan adalah metode kuantitatif. Analisis statistik yang digunakan dalam penelitian ini adalah asumsi klasik, regresi linier berganda koefisien determinasi, metode uji $t$ dan uji F. Hasil Uji $t$ parsial CR thitung = 1,155 < 2,262 ttabel dengan nilai signifikansi 0,278 > 0,05, dapat dikatakan bahwa H0 diterima yang artinya CR tidak berpengaruh terhadap Nilai Perusahaan, DER thitung = 5,147 > 2,306 ttabel dengan nilai signifikan 0,001 <0,05, Hal ini dapat dikatakan bahwa H0 ditolak yang artinya DER Terdapat pengaruh terhadap Nilai Perusahaan signifikansi 0,03 < 0,05 Hal ini dapat dikatakan bahwa H0 diterima dan Ha ditolak yang artinya CR,DER berpengaruh namun tidak signifikan terhadap Nilai Perusahaan. Regresi linier berganda Y = -26,274 + 0,058X1 + 0,293X2

Kata Kunci: Current Ratio (CR), Debt to Equity Ratio (DER), dan Nilai Perusahaan

\section{Abstract}

This study aims to determine the effect of Current Ratio (CR) and Debt to Equity Ratio (DER) on Return on Assets (ROA) at PT Astra International, Tbk partially and simultaneously..The method used is quantitative method.The statistical analysis used in this study is the classical assumption, multiple linear regression, coefficient of determination, the $t$ test method and the F test.Based on the research results of the partial $t$ test $C R t$ count $=$ $1.155<2.262 t$ table with a significance value of $0.278>0.05$. , 05, It can be said that $H 0$ is rejected, which means that DER has an effect on Firm Value, significance of $0.03<0.05$. Multiple linear regression $Y=-26,274+$ $0,058 X 1+0,293 X 2$
\end{abstract}

Keywords: Current Ratio (CR), Debt to Equity Ratio (DER), and Company Value

\section{PENDAHULUAN}

Indonesia menjadi negara tujuan utama untuk investasi di sektor otomotif. Produk-produk yang diluncurkan juga semakin canggih mengikuti perkembangan teknologi guna memenuhi kepuasan para konsumen. Perusahaan-perusahaan tersebut tentunya banyak melakukan upaya guna mengikuti perkembngan teknologi. Upaya tersebut tidak terlepas dari biaya atau modal yang digunakan untuk melakukan pengembangan produk dan biaya promosinya. Perusahaan-perusahaan otomotif dituntut untuk meningkatkan kinerjanya agar dapat bersaing dan memperoleh laba yang berkesinambungan.laba yang diperoleh tentunya merupakan salah satu tujuan perusahaan sebagai institusi bisnis.

Dalam mencapai tujuan tersebut, perusahaan harus inovatif dan mampu melakukan penyesuaian diri terhadap perubahan-perubahan di regional dan dalam negeri seperti kebijakan-kebijakan .Analisa laporan keuangan sangat penting dilakukan untuk mengetahui dan menilai tingkat kesehatan perusahaan. Kemampuan perusahaan dapat dilihat dalam membayar hutang-hutangnya, baik hutang jangka panjang maupun jangka panjang, memanfaatkan aset yang dimiliki secara optimal, dan kemampuan perusahaan dalam memperoleh keuntungan, baik dalam penjualan, aset, maupun modal 
saham.Perusahaan otomotif yang terdaftar di Bursa Efek Indonesia terdiri dari berbagai macam jenis operasionalnya. PT Astra International Tbk atau Astra International merupakan salah satu perusahaan yang berkomitmen untuk menjadi perusahaan pembiayaan terbaik dan terkemuka di indonesia. Astra International hadir untuk melayani beragam pembiayaan seperti kendaraan bermotor baik kendaraan rodoa dua, maupun kendaraan roda empat baru maupun bekas, komponen pendukung kendaraan, serta berbagai produk jasa terkait otomotif lainnya.Astra International yang bermarkas di Jakarta, Indonesia.

Perusahaan ini didirikan pada tahun 1957 dengan nama PT Astra International Incorporated. Pada tahun 1990, perseroan mengubah namanya menjadi PT Astra International Tbk .Perusahaan ini telah tercatat di Bursa Efek Indonesia dengan kode saham ASII sejak tanggal 04 April 1990.Per 30 Juni 2018, Mayoritas saham astra dimiliki oleh Jardine Cycle \& Carriage Ltd. Sebesar 50,11\%. Sampai dengan Desember 2017, Grup Astra mempekerjakan lebih dari 218.000 karyawan di 212 .Jumlah ini bertumbuh hiungga 221.719 per Juni 2018. Astra International pada awalnya didirikan oleh Tjia Kian Liong (William Soerjadjaja), Tjia Kin Joe (Benyamin), dan Liem Peng Hong pada tahun 1950-an. Perusahaan ini pada awalnya menempati sebuah toko di Jalan Sabang no. 36A, Jakarta.

Nama Astra sendiri diusulkan oleh Kian Tie, adik Kian Liong, dalam bahasa Latin yang berarti bintang. Ketiga pendirinya kemudian mendaftarkan nama Astra International Inc. ke notaris Sie Khwan Djioe pada tanggal 20 Februari 1957 dengan modal sejumlah 2,5 juta rupiah. Pada awal berdirinya perusahaan ini menjadi distributor dan importir limun merek Prim Club Kornet CIP.

Mulai tahun 1970, Astra secara perlahan-lahan ditunjuk menjadi distributor dari berbagai hasil produksi Jepang, di antaranya menjadi distributor tunggal sepeda motor Honda serta distributor alat-alat perkantoran produksi
Fuji Xerox di Indonesia. Untuk mendukung produksi di Indonesia, Astra juga mendirikan PT Federal Motor (kini PT Astra Honda Motor) untuk menjadi pabrik perakitan sepeda motor Honda di Indonesia pada tahun 1971. Astra memasuki bisnis perdagangan dan penyewaan alat berat melalui pendirian PT United Tractors pada tahun 1972. Sementara itu, Astra juga ditunjuk menjadi agen tunggal pemasaran produk-produk Daihatsu pada tahun 1973, hingga mendirikan PT Daihatsu Indonesia (kini PT Astra Daihatsu Motor) pada tahun 1978.

Lebih lanjut dari penunjukkan Astra sebagai distributor kendaraan bermotor Toyota, Astra kemudian mendirikan ventura bersama dengan Toyota Motor Corporation di Jepang, yaitu perusahaan PT Toyota-Astra Motor (TAM) pada tahun 1971, yang menjadi perusahaan distribusi kendaraan bermerek Toyota di Indonesia. TAM kemudian meluncurkan mobil Toyota Kijang pertama pada tahun 1977, salah satu tipe mobil keluarga pionir di Indonesia. Pada tahun 1990, Astra melalukan penawaran umum perdana atas 30 juta lembar sahamnya di Bursa Efek Jakarta (kini Bursa Efek Indonesia). Pada tahun 2004, Astra bekerja sama dengan Standard Chartered Bank melakukan pengambilalihan atas Bank Permata, sebuah bank hasil merger dari lima bank yang berada di bawah pengawasan Badan Penyehatan Perbankan Nasional (BPPN), yaitu PT Bank Bali Tbk, PT Bank Universal Tbk, PT Bank Prima Express, PT Bank Artamedia, dan PT Bank Patriot. Kepemilikan gabungan Astra bersama dengan Standard Chartered Bank mencapai 89,12\% sejak 2006 hingga kini.Saat ini, sebanyak 50,11 persen saham Astra International dikuasai oleh Jardine Cycle \& Carriage Limited, sebuah perusahaan yang berbasis di Singapura.Pada tahun 2016, Astra meluncurkan lini bisnisnya yang ketujuh, yaitu lini bisnis properti.

Pada tahun 1990, Astra melalukan penawaran umum perdana atas 30 juta lembar sahamnya di Bursa Efek Jakarta (kini Bursa Efek Indonesia).Pada tahun 
2004, Astra bekerja sama dengan Standard Chartered Bank melakukan pengambilalihan atas Bank Permata, sebuah bank hasil merger dari lima bank yang berada di bawah pengawasan Badan Penyehatan Perbankan Nasional (BPPN), yaitu PT Bank Bali Tbk, PT Bank Universal Tbk, PT Bank Prima Express, PT Bank Artamedia, dan PT Bank Patriot. Kepemilikan gabungan Astra bersama dengan Standard Chartered Bank mencapai 89,12\% sejak 2006 hingga kini.Saat ini, sebanyak 50,11 persen saham Astra International dikuasai oleh Jardine Cycle \& Carriage Limited, sebuah perusahaan yang berbasis di Singapura.Pada tahun 2016, Astra meluncurkan lini bisnisnya yang ketujuh, yaitu lini bisnis properti. berbagai hubungan dan indikator keuangan, yang ditujukan untuk menunjukan perubahan dalam kondisi keuangan atau prestasi operasi dimasa lalu dan membantu menggambarkan trend pola perubahan tersebut, untuk kemudian menunjukkan risiko dan peluang yang melekat pada perusahaan yang bersangkutan. Rasio Keuangan menjadi dasar untuk menjawab beberapa pertanyaan penting mengenai kesehatan keuangan, diantaranya adalah Rasio Likuiditas merupakan rasio yang digunakan untuk mengukur seberapa likuidnya suatu perusahaan.

Apabila current ratio $1: 1$ atau $100 \%$ berarti bahwa aktiva lancar dapat menutupi semua hutang lancar. Current Ratio yang tinggi mungkin menunjukkan adanya uang kas yang berlebihan dibanding dengan tingkat kebutuhan atau adanya unsur aktiva lancar yang rendah likuiditasnya (seperti persediaan) yang berlebihan.

Debt to Equity Ratio pada PT. Astra International Tbk Periode 2009-2019 dapat disimpulkan Angka tertinggi (kenaikan) terjadi pada tahun 2010, yang berada dikisaran $109,85 \%$ hal ini menunjukkan bahwa di tahun 2010 kebutuhan ekuitas dipenuhi dari hutang sehingga beban perusahaan terhadap pihak luar besar juga.

Nilai Perusahaan pada PT. Astra International, Tbk. Periode 2009-2019 dapat pada tahun 2015 mengalami penurunan hal ini disebabkan oleh penjualan pada perusahaan yang menurun serta kinerja perusahaan yang menurun.

\section{TINJAUAN PUSTAKA}

1. Laporan Keuangan

Menurut Kasmir (2018:7) laporan keuangan adalah laporan yang menunjukkan kondisi keuangan perusahaan pada saat ini atau dalam suatu periode tertentu

2. Rasio Solvabilitas

Menurut Kasmir (2012: 151), rasio solvabilitas (leverage ratio) "adalah rasio yang digunakan untuk mengukur sejauh mana untuk mengukur kemampuan perusahaan untuk membayar seluruh kewajibannya, baik jangka pendek maupun jangka panjang apabila perusahaan dilikuidasi". Sedangkan menurut Sutrisno (2009), mendefinisikan Solvabilitas adalah kemampuan perusahaan untuk memenuhi semua kewajibannya apabila perusahaan dilikuidasi

3. Rasio Profitabilitas

Menurut Kasmir (2012: 196) "rasio profitabilitas merupakan rasio untuk menilai kemampuan perusahaan dalam mencari keuntungan" Rasio ini juga memberikan ukuran tingkat efektivitas manajemen suatu perusahaan.

4. Rasio Aktivitas

Menurut Kasmir (2012:172) "rasio aktivitas merupakan Rasio aktivitas (activity ratio) merupakan rasio yang digunakan untuk mengukurefektivitas perusahaan dalam menggunakan aktiva yang dimilikinya. Atau dapatpula dikatakan rasio ini digunakan untuk mengukur tingkat efisiensi (efektivitas) pemanfaatan sumber daya perusahaan.

5. Rasio Nilai Pasar

Menurut Irham Fahmi (2013:138) "rasio nilai pasar merupakan rasio yang yang menggambarkan kondisi yang terjadi di pasar. Rasio ini mampu memberi pemahaman bagi pihak manajemen perusahaan terhadap kondisi penerapan yang akan 
dilaksanakan dan dampaknya pada masa yang akan datang

6. Nilai Perusahaan

Tujuan utama perusahaan adalah memaksimalkan keuntungan atau kekayaan, terutama bagi para pemegang sahamnya, terwujud berupa upaya peningkatan atau memaksimalkan nilai pasar atas harga saham perusahaan yang bersangkutan. Tujuan ini bersifat garis besar, karena pada praktiknya tujuan itu senantiasa dipengaruhi oleh keputusankeputusan dibidang keuangan (Tika, 2012:124).

\section{METODE}

Jenis penelitian yang digunakan dalam penulisan skripsi ini adalah penelitian deskriptif dan menggunakan data kuantitatif, yakni penelitian, yang menggunakan data numerik dan statistik menggunakan data skunder. Dalam penelitian ini variabel yang digunakan adalah Current Ratio, Debt to Equity Ratio danNilai Perusahaan.

Data yang diambil untuk penelitian penelitian ini berupa Laporan Laba Rugi dan Neraca PT. Astra International, Tbk dari tahun 2009-2019.

Populasi dalam penelitian ini adalah laporan keuangan PT. Astra International Tbk. Sample dalam penelitian ini adalah laporan keuangan perusahaan berupa neraca dan laporan laba rugi pada PT. Astra International Tbk. Periode tahun 2009-2019. Teknik analisis data

1. Analisis Regresi Linier Berganda
a. Uji Hipotesis
b. Uji t
c. Uji Autokorelasi
d. Uji multikoliniearitas

2. Analisis Regresi Linear Sederhana

\section{HASIL DAN PEMBAHASAN}

1. Analisis

2. Regresi Linear Sederhana

Tabel 1. Hasil Analisis Regresi Linear Sederhana

Coefficients ${ }^{a}$

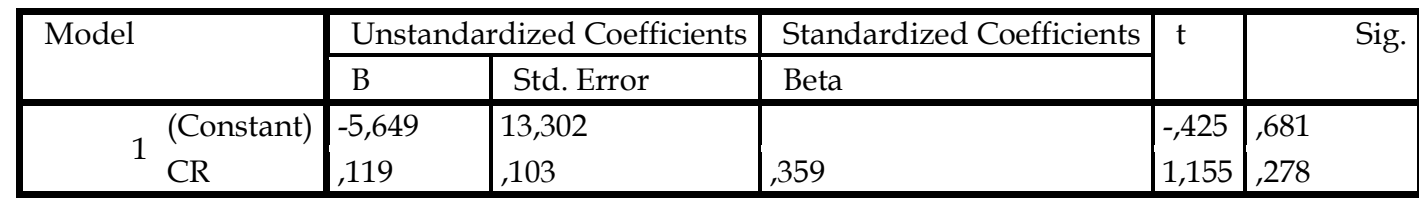

a. Dependent Variable: ROA

Berdasarkan hasil dari output yang disajikan pada tabel diatas maka dapat diperoleh persamaan regresi sebagai berikut $: Y=a+b X 1=-5,649+0,119 X 1$

Artinya: Current ratio memiliki arah hubungan Positif terhadap Return on Asset . Interprestasi dari persamaan regresi linear sederhana yang Konstanta yang dihasilkan dari hasil perhitungan diatas diperoleh hasil sebagai berikut:

a. konstanta sebesar $-5,649$ yang berarti hal ini menunjukan bahwa apabila variabel current ratio $=0$, maka variabel dependen return on asset akan mengalami prubahan sebesar 5,649

b. Variabel current ratio mempunyai nilai koefisien sebesar 0,119 dengan nilai Positif. Hal ini dapat diartikan apabila nilai current ratio mengalami perubahan sebesar $1 \%$ dan variabel independen bersifat tetap maka nilai return on asset akan mengalami peningkatan sebesar 0,119

Tabel 2. Hasil Uji t parsial

Coefficients ${ }^{a}$

\begin{tabular}{|c|c|c|c|c|c|}
\hline \multirow[t]{2}{*}{ Model } & \multicolumn{2}{|c|}{ Unstandardized Coefficients } & Standardized Coefficients & \multirow[t]{2}{*}{$\mathrm{t}$} & \multirow[t]{2}{*}{ Sig } \\
\hline & B & Std. Error & Beta & & \\
\hline $\begin{array}{ll} & \text { (Constant) } \\
\text { CR }\end{array}$ & $\begin{array}{l}-5,649 \\
, 119\end{array}$ & $\begin{array}{l}13,302 \\
, 103\end{array}$ & ,359 & $\begin{array}{l}-, 425 \\
1,155\end{array}$ & $\begin{array}{l}681 \\
278\end{array}$ \\
\hline
\end{tabular}


a. Dependent Variable: ROA

Pada tabel diatas dinyatakan bahwa uji t antara current ratio terhadap return on asset sebesar yaitu thitung 1,155 dengan tingkat signifikasi 0,278 serta derajat kebebasan a/2 $=0,05: 2, \mathrm{df}$ $=\mathrm{n}-2(11-2=9)$ maka 0,025:9 maka diperoleh nilai ttabel2,262. Maka dapat diketahui bahwa thitung $=1,155<2,262$ ttabeldengan nilai siginifikansi 0,278 > 0,05 sehingga tidak ada pengaruh current ratio terhadap return on asset sehingga $\mathrm{H} 0$ diterima yang artinya bahwa secara parsial current ratio tidak berpengaruh terhadap return on asset.

3. Koefisien Korelasi

Tabel 3. Hasil Koefisien Korelasi

Summary

\begin{tabular}{|l|c|l|l|l|}
\hline Model & $\mathrm{R}$ & $\mathrm{R}$ Square & Adjusted R Square & Std. Error of the Estimate \\
\hline 1 &, $359 \mathrm{a}$ &, 129 &, 032 & 2,51108 \\
\hline
\end{tabular}

Dari hasil output SPSS yaitu model summary pada tabel diatas, dapat dilihat bahwa angka R (nilai koefisien korelasi) adalah sebesar 0,359 Nilai tersebut menunjukan bahwa hubungan antara current ratio dengan return on asset adalah Tinggi.

4. Koefisien Determinasi

Tabel 4. Hasil Koefisien Determinasi

Model Summary

\begin{tabular}{|l|l|l|l|l|}
\hline Model & $\mathrm{R}$ & R Square & Adjusted R Square & Std. Error of the Estimate \\
\hline 1 &, $359 \mathrm{a}$ &, 129 &, 032 & 2,51108 \\
\hline
\end{tabular}

a. Predictors: (Constant), CR

$$
\begin{aligned}
\mathrm{KD} & =\mathrm{R} 2 \times 100 \% \\
& =(0,359) 2 \times 100 \% \\
& =0,128881 \times 100 \%=12,8 \%
\end{aligned}
$$

Hasil data diatas pada tabel 4.10 menunjukan bahwa koefisien determinasi ( $\mathrm{R}$ square) sebesar 0,128881 atau sebesar $12,8 \%$ yang artinya memberikan kontribusi yang Sangat Kuat antara variabel current ratio terhadap variabel return on asset. Hal ini sesuai dengan tabel di atas terdapat Pengaruh Debt to Equity Ratio terhadap

\begin{tabular}{|c|c|c|c|c|c|}
\hline \multirow[t]{2}{*}{ Model } & \multicolumn{2}{|c|}{ Unstandardized Coefficients } & Standardized Coefficients & \multirow[t]{2}{*}{$\mathrm{t}$} & \multirow[t]{2}{*}{ Sig. } \\
\hline & $\bar{B}$ & Std. Error & Beta & & \\
\hline $\begin{array}{l}\text { (Constant) } \\
\text { DER }\end{array}$ & $\begin{array}{l}-20,174 \\
307\end{array}$ & $\begin{array}{l}5,817 \\
, 060\end{array}$ & 864 & $\begin{array}{l}-3,468 \\
5,147\end{array}$ & $\begin{array}{l}007 \\
, 001\end{array}$ \\
\hline
\end{tabular}

Tabel 5. Analisis Regresi Linear Sederhana

Coefficients

a. Dependent Variable: ROA

Konstanta yang dihasilkan dari hasil perhitungan diatas diperoleh hasil konstanta sebesar -20,174 yang berarti
Return On Asset Pada PT. Astra Internatioanal , Tbk.

a. Uji Analisis Regresi Linear Sederhana Untuk mengetahui seberapa besarpengaruh Debt to EquityRatio (DER) terhadap Return On Asset (ROA) akan disajikan hasil olahan data dengan menggunakan aplikasi SPSS versi 20 yang dapat dilihat pada tabel sebagai berikut: 
mengalami perubahan sebesar -20,174.

Variabel Debt to Equity Ratio mempunyai nilaikoefisien sebesar 0,307

Bertanda positif, Hal ini dapat diartikan apabila nilai Debt to Equity Ratio mengalami perubahan sebesar 1\% dan variabel independen bersifat tetap maka nilai return on asset akan mengalami peningkatan sebesar 0,307

b. Uji Signifikan Parsial (Uji t)

Tabel 6. Hasil Uji t parsial

Coefficients ${ }^{a}$

\begin{tabular}{|l|l|l|l|l|l|}
\hline \multirow{2}{*}{ Model } & \multicolumn{2}{|c|}{ Unstandardized Coefficients } & Standardized Coefficients & $t$ & Sig. \\
\cline { 2 - 4 } & \multicolumn{1}{|c|}{ B } & \multicolumn{1}{|c|}{ Std. Error } & Beta & & \\
\hline \multirow{2}{*}{$\begin{array}{l}\text { (Constant) } \\
\text { DER }\end{array}$} & $-20,174$ & 5,817 & & $-3,468$ &, 007 \\
DER &, 307 &, 060 &, 864 & 5,147 &, 001 \\
\hline
\end{tabular}

a. Dependent Variable: ROA

Pada tabel Diatas dinyatakan bahwa uji $t$ antara debt to equity ratio terhadap return on asset sebesar yaitu thitung 5,147dengan tingkat signifikasi 0,05 serta derajat kebebasan a / $2=0,05: 2$ , $\mathrm{df}=\mathrm{n}-\mathrm{k}(11-2=9)$ maka 0,025: 9 maka diperoleh nilai ttabel 2,364 Maka dapat c. Koefisien Korelasi diketahui bahwa thitung $=5,147>$ ttabel $=2,306$ dengan nilai signifikan $0,001<$ 0,05 sehingga berpengaruh debt to asset ratio terhadap return on asset, sehingga H0 ditolak, yang artinya bahwa secara parsial berpengaruh terhadap return on asset.

Tabel 7. Hasil Koefisien Korelasi

\begin{tabular}{|l|r|l|l|l|}
\hline Model & $\mathrm{R}$ & R Square & Adjusted R Square & Std. Error of the Estimate \\
\hline 1 &, $864^{\mathrm{a}}$ &, 746 &, 718 & 1,35498 \\
\hline
\end{tabular}

a. Predictors: (Constant), DER

Dari hasil output SPSS yaitu model summary pada tabel 4.13 diatas, dapat dilihat bahwa angka $\mathrm{R}$ (nilai koefisien korelasi) adalah sebesar 0,864. Nilai tersebut menunjukan bahwa hubungan antara debt to equity ratio dengan return on asset adalah Tinggi Hal ini sesuai dengan tabel 3.2.

d. Koefisien Determinasi

Tabel 8. Hasil Koefisien Determinasi

Model Summary

\begin{tabular}{|l|r|l|l|l|}
\hline Model & $\mathrm{R}$ & R Square & Adjusted R Square & Std. Error of the Estimate \\
\hline 1 &, $864^{\mathrm{a}}$ &, 746 &, 718 & 1,35498 \\
\hline
\end{tabular}

a. Predictors: (Constant), DER

$\mathrm{KD}=\mathrm{R} 2 \times 100 \%=(0,864) 2 \times 100 \%=$ $74,64 \%$
Hasil
data
diatas
pada tabelmenunjukan bahwa koefisien determinasi ( $\mathrm{R}$ Square) sebesar 0,746496 atau sebesar $74,64 \%$ yang artinya memberikan kontibusi yang tinggi sekali

Tabel 9. Hasil Regresi Berganda

Coefficientsa

\begin{tabular}{|l|l|l|l|l|l|}
\hline \multirow{2}{*}{ Model } & \multicolumn{2}{|l|}{ Unstandardized Coefficients } & Standardized Coefficients & \multirow{2}{*}{$\mathrm{t}$} & \multirow{2}{*}{ Sig. } \\
\cline { 2 - 5 } & $\mathrm{B}$ & Std. Error & Beta & & $-3,144$ \\
\hline 1 & (Constant) & $-26,274$ & 8,356 & & \\
\hline
\end{tabular}

antara variabel debt to equity ratio terhadap variabel return on asset.

e. Analisis Regresi Berganda

Pengaruh Current Ratio ,Debt to Equity Ratio terhadap Return On AssetPada PT. Astra International, Tbk. 


\begin{tabular}{|l|l|l|l|l|l|}
\hline DER &, 293 &, 061 &, 825 & 4,797 &, 001 \\
CR &, 058 &, 057 &, 175 & 1,015 &, 34 \\
\hline
\end{tabular}

a. Dependent Variable: ROA

Hasil model regresi berganda diatas menunjukkan arah pengaruh dari setiap variabel independen yang terdiri dari CR, DER terhadapvariabel dependen ROA. Hasil persamaan Regresi sebagai berikut :

$\mathrm{Y}=-26,274+0,058 \mathrm{X} 1+0,293 \mathrm{X} 2$

Artinya jika CR sebagai X1, DER sebagai $\mathrm{X} 2$, nilainya 0 (Nol) maka presentase ROA adalah sebesar -26,274.Selanjutnya koefisien regresi variabel CR diperoleh sebesar 0,058 dengan arah koefisien positif. Hal ini menunjukkan bahwa apabila setiap CR naik 1 (satu) satuan maka akan mengakibatkan penurunan ROA sebesar 0,058. Koefisien regresi variabel DER diperoleh sebesar 0,293 dengan arah koefisien positif. Hal ini menunjukkan bahwa apabila setiap perubahan 1 (satu) satuan maka akan mengalami penuruan ROA sebesar 0,293 maka dapat ditarik kesimpulan bahwa dari hasil model regresi CR dan DER memiliki koefisien positif yang artinya akan memberikan peningkatan terhadap ROA.

Tabel 10. Hasil Uji t

\begin{tabular}{|c|c|c|c|c|c|}
\hline \multirow{2}{*}{ Model } & \multicolumn{2}{|c|}{ Unstandardized Coefficients } & \multirow{2}{*}{$\frac{\text { Standardized Coefficients }}{\text { Beta }}$} & \multirow{2}{*}{$\mathrm{T}$} & \multirow{2}{*}{ Sig } \\
\hline & B & Std. Error & & & \\
\hline (Constant) & $-26,274$ & 8,356 & & $-3,144$ & ,014 \\
\hline DER & 293 & ,061 & 825 & 4,797 & ,001 \\
\hline CR & , 058 & 057 & 175 & 1,015 & ,34 \\
\hline
\end{tabular}

a. Dependent Variable: ROA

Berdasarkan Tabel uji $\mathrm{t}$ di peroleh hasil sebagai berikut :

1) Variable $C R$ diatas diperoleh nilai thitungsebesar 1,015, selanjutnya mencari ttabel a $=0,05(\mathrm{a} / 2)=0,025$

$(\mathrm{df}=\mathrm{n}-\mathrm{k}-1)$

Df $=0,025$

$\mathrm{N}=$ tahun $(11)$

$\mathrm{K}=$ variable bebas $(2)$

Df $(0,025): 8=2,306$

Maka dapat diketahui bahwa thitung $<$ ttabel $=1,015<2,306$ Dengan nilai signifikan 0,5340>0,05, Maka Hoditerima yang artinya tidak ada pengaruh secara parsial CR (X1) terhadap ROA (Y)

Tabel 11. Hasil Statistik Uji F

ANOVA $^{a}$

\begin{tabular}{|c|c|c|c|c|c|}
\hline Model & Sum of Squares & Df & Mean Square & F & Sig. \\
\hline Regression & 50,524 & 2 & 25,262 & 13,806 &, $003^{\mathrm{b}}$ \\
Residual & 14,638 & 8 & 1,830 & & \\
Total & 65,162 & 10 & & & \\
\hline
\end{tabular}

a. Dependent Variable: ROA

b. Predictors: (Constant), CR, DER

Sumber : Data diolah dengan SPSS V20

Dari tabel ANOVA atau uji $F$, Menunjukan bahwa nilai Fhitung= 13,806 dengan signifikan sebesar
2) Variable DER diatas diperoleh nilai thitung sebesar 4,797 , selanjutnya mencari ttabel $\mathrm{a}=0,05(\mathrm{a} / 2)=0,025$

$(\mathrm{df}=\mathrm{n}-\mathrm{k}-1)$

Df $=0,025$

$\mathrm{N}=$ tahun (11)

$\mathrm{K}=$ variable $(3)$

Df $(0,025): 7=2,364$

Maka dapat diketahui bahwa thitung $>$ ttabel $=4,797>2,364$ dengannilai signifikan 0,43>0,05, Maka Ho ditolak yang artinya terdapat pengaruhsecara parsial DER (X2) terhadap ROA (Y)
0,003 selanjutnya mencari Ftabel dengan perhitungan sebagai berikut :

$\mathrm{F}$ tabel $=\mathrm{df} 1=\mathrm{K}-1=3-1=2$

$\mathrm{df} 2=\mathrm{n}-\mathrm{k}=11-3=8$ 
Maka diperoleh Ftabel 4,46, sehingga Fhitung $>$ Ftabel13,806 $>4,46$ dan nilaisignifikan $0,03<0,05$. Maka keputusannya Ho ditolak yang artinya berpengaruh dan tidak signifikan terhadap Nilai Perusahaan .

\section{Tabel 12. Koefisien Kolerasi}

Model Summaryb

\begin{tabular}{|l|l|l|l|l|}
\hline Model & $\mathrm{R}$ & R Square & Adjusted R Square & Std. Error of the Estimate \\
\hline 1 &, $881^{\mathrm{a}}$ &, 775 &, 719 & 1,35270 \\
\hline
\end{tabular}
a. Predictors: (Constant), CR, DER
b. Dependent Variable: ROA

Dari hasil output SPSS yaitu model summary pada tabel 4.18 diatas, dapat dilihat bahwa angka $\mathrm{R}$ (nilai korelasi) adalah sebesar 0,881. Nilai Koefisien Kolerasi tersebutmenunjukan bahwa hubungan antara current ratio, debt to asset ratio dengan returnon asset adalah Tinggi. Hal ini sesuai dengan tabel

\begin{tabular}{|l|l|l|l|l|}
\hline \multicolumn{4}{|c|}{ Tabel 13. Model Summary } \\
\hline Model & $\mathrm{R}$ & R Square & Adjusted R Square & Std. Error of the Estimate \\
\hline 1 &, $881^{\mathrm{a}}$ &, 775 &, 719 & 1,35270 \\
\hline
\end{tabular}

b. Dependent Variable: ROA

$\mathrm{KD}=\mathrm{R} 2 \times 100 \%$

$=(0,881) 2 \times 100 \%$

$=0,776161 \times 100 \%$

$=77,6 \%$

Hasil data diatas pada tabel menunjukan bahwa koefisien determinasi sebesar 0,776161 atau sebesar 77,6\% yang artinyamemberikan kontribusi yang Rendah sekali antara variabel current ratio, debt to asset ratioterhadap variabel return on asset. Hal ini sesuai dengan tabel

\section{KESIMPULAN}

Pengaruh CR terhadap Nilai Perusahaan pada PT Astra Internasional Tbk Tahun 2009-2019. Berdasarkan hasil penelitian bahwa thitung <ttabel $=1,015<$ 2,306 dengan nilai signifikan 0,5340 >0,05, Maka Hoditerima yang artinya tidak ada pengaruh secara parsial CR terhadap Nilai Perusahaan.

Pengaruh DER terhadap Nilai Perusahaan pada PT Astra International Tbk Tahun 2009-2019. Berdasarkan hasil penelitian bahwa thitung $>$ ttabel $=4,797>$ 2,364 dengannilai signifikan 0,43> 0,05, Maka Ho ditolak yang artinya terdapat pengaruh secara parsial DER terhadap nilai perusahaan.

Pengaruh CR dan DER secara bersama-sama terhadap Nilai Perusahaan pada PT Astra International Tbk tahun 2009-2019. Berdasarkan hasil penelitian bahwa diperoleh Ftabel 4,46, sehingga Fhitung > Ftabel 13,806 > 4,46 dan nilai signifikan $0,03<0,05$. Maka keputusannya Ho ditolak yang artinya Terdapat pengaruh namun tidak signifikan terhadap Nilai Perusahaan.

\section{DAFTAR PUSTAKA}

Abdullah, M. 2014. Manajemen dan evaluasi Kinerja Karyawan. Yogyakart: Penerbit Aswaja Pressindo.

Amelia, R. W., \& Sunarsi, D. (2020). Pengaruh Return On Asset Dan Return On Equity Terhadap Debt To Equity Ratio Pada PT. Kalbe Farma, TBK. Ad Deenar: Jurnal Ekonomi dan Bisnis Islam, 4(01), 105-114.

Anjayani, NS., Lutfi, AM., Suhartono, A., Sari, WI., Sunarsi, D. (2020). Pengaruh Perputaran Persediaan dan Rasio Perputaran Aktiva Terhadap Return on Invesment Pada PT Gudang Garam Tbk. TIN: Terapan Informatika Nusantara. Vol. Issue 4 Pages 171-176 Arikunto,s. 2013. Prosedur penelitian suatu pendekatan praktik Yogyakarta: bpfe

Basuki, Arief. 2012. Analisis Pengaruh Cash Ratio, Debt To Total Assets Ratio, Debt Equity Ratio, Return On Assets, 
Dan Net Profit Margin Terhadap Dividen Payout Ratio Pada Perusahaan Otomotif Yang Listing Di Bursa Efek Indonesia Periode 20072011. Skripsi S1 Universitas Diponegoro, Semarang.

Fahmi, i. 2011. "analisis laporan keuangan". Bandung : alfabeta

Ghozali, i. 2013. "aplikasi analisis multivariate dengan program ibm spss 20". Semarang: badan penerbit universitas di ponegoro.

Harahap, s. S. analisis kritis atas laporan keuangan (11 ed.),Jakarta barat : rajawali pers.

Hidayat, A., \& Sunarsi, D. (2020). FaktorFaktor Yang Mempengaruhi Dana Pihak Ketiga Dan Dampaknya Terhadap Profitabilitas (Survey Pada Bpr Syariah Di Jawa Barat Tahun 2014-2017). Jurnal Proaksi, 7(1), 54-65.

K Nufus, H Supratikta, A Muchtar, D Sunarsi. (2020). Analysis of Financial Performance: Case Study of PT. X Employee Cooperative. Utopía Y Praxis Latinoamericana. Vol. 25. Pages 429-444

Kasmir. (2012). Analisis laporan keuangan. Jakarta: pt. Raja grafindo persada.

Nofiana, L., \& Sunarsi, D. (2020). The Influence of Inventory Round Ratio and Activities Round Ratio of Profitability (ROI). JASa (Jurnal Akuntansi, Audit dan Sistem Informasi Akuntansi), 4(1), 95-103.

Nufus, Khayatun dan Awaluddin Muchtar, 2019, Belajar Praktis Manajemen Keuangan, Edisi Pertama, Makasaar: Sahabat Pena.
Martono dan Agus Harjito. 2010, "Manajemen Keuangan Edisi 3" Yogyakarta: Ekonisia.

Rakhimsyah, Lely Amnah dan Barbara Gunawan. 2011. Pengaruh Keputusan Investasi, Keputusan Pendanaan, Kebijakan Dividen dan Tingkat Suku Bunga Terhadap Nilai Perusahaan. Jurnal Investasi, 7(1), h: 31-4

Sugiyono. (2010). Metode penelitian penelitian pendekatan kuantitatif, kualitatifdan $r \mathcal{E} d$. Bandung: alfabeta.

Suhartono, A., Jati, W., \& Sunarsi, D. (2019). Pengaruh Earning Per Share Dan Return On Asset Terhadap Harga Saham Pada PT. Bank Negara Indonesia Tbk Periode 2009-2018. Jurnal Manajemen, Bisnis dan Organisasi (JUMBO), 3(3), 182-194.

Susanti, N., Latifa, I., \& Sunarsi, D. (2020). The Effects of Profitability, Leverage, and Liquidity on Financial Distress on Retail Companies Listed on Indonesian Stock Exchange. Jurnal Ilmiah Ilmu Administrasi Publik, 10(1), 45-52.

Syamsuddin. (2010).Manajemen keuangan perusahaan. Jakarta: pt .Rajagrafindo persada.

Sari, Oktavina Tiara. 2013. Pengaruh Keputusan Investasi, Keputusan Pendanaan dan Kebijakan Dividen Terhadap Nilai Perusahaan. Management Analysis Journal, 2(2), h: 1-7.

Tri Wartono.(2018)." Pengaruh current ratio, debt to equity ratio terhadap return on asset pada pt. Astra international.Tangerang selatan penerbit universitas pamulang. 